\title{
Saliva testing for Helicobacter pylori infection in children and adolescents - a literature review
}

\author{
Magdalena Zakrzewska', Mateusz Zakrzewski ${ }^{1}$, Anna Gladka', \\ Katarzyna Czarniecka-Barglowska², Elżbieta Maciorkowska³ \\ 'Department of Developmental Age Medicine and Paediatric Nursing, Medical University of Bialystok, Bialystok, Poland \\ 2Department of Maxillofacial Surgery, University Clinical Hospital in Bialystok, Bialystok, Poland \\ ${ }^{3}$ Department of Pediatrics and Pulmonary Diseases, University Clinical Hospital in Bialystok, Bialystok, Poland
}

\section{ABSTRACT}

Helicobacter pylori is known as one of the most common Gram-negative bacteria in the world. Infection takes place via oral-oral, gastro-oral, and faecal-oral routes. The oral-oral route is considered to be the most common route of transmission. The presence of $H$. pylori in the saliva is considered as a factor inducing periodontal disease and tooth decay, as well as changes such as aphthous ulcers, leucoplakia, and lichen planus. Furthermore, existing bacteria in dental plaques such as Streptococcus mutans and Prevotela intermedia may produce bacteriocins that promote the growth of $H$. pylori. Recent studies have focused on infection of H. pylori mainly in adults, although infection often occurs in early childhood. As such, more studies concerning the developmental population are needed. Saliva, as an easily available biological material, may soon become an important source in the diagnosis of $H$. pylori infections, especially in children and adolescents.

KEY WORDS:

children, Helicobacter pylori, saliva.

\section{INTRODUCTION}

Helicobacter pylori is a Gram-negative rod of which humans are the main carriers. Its natural habitat of development is chiefly the mucus covering the stomach epithelium. The bacterium was discovered by Valery Jaworski. However, 30 years ago Barry Marshall and Robin Warren showed the relationship of $H$. pylori infection with inflammation of the stomach and duodenum. In 1994, the bacterium was recognised by the International Agency for Research on Cancer as a class 1 carcinogen involved in the pathogenesis of gastric cancer [1].
The prevalence of $H$. pylori infection in the human population around the world is estimated to be, on average, $50 \%$ and seems to be on the decline. According to epidemiological data $84 \%$ of adults and $32 \%$ of children were infected in Poland in 2004 [2], while a study carried out in 2010 in children in urban areas of Upper Silesia showed $H$. pylori infection in only $15.7 \%$ of the examined group. This lower incidence of infection seems to be related to the improvement of socio-economic conditions, greater attention to individual hygiene, the use of probiotics, and frequent antibiotic therapy commonly applied in children due to respiratory tract infections [3-5].

\section{ADDRESS FOR CORRESPONDENCE:}

Magdalena Zakrzewska, Department of Developmental Age Medicine and Paediatric Nursing, Medical

University of Bialystok, 37 Szpitalna St., 15-001 Bialystok, ORCID: 0000-0002-2756-6659,

e-mail: magdalena.maciorkowska@gmail.com 


\section{REVIEW}

\section{EPIDEMIOLOGY AND ROUTES OF HELICOBACTER INFECTION ACQUISITION}

Infection takes place via the oral-oral, gastro-oral, and faecal-oral routes [1]. In each of these three routes of transmission, infection occurs through the oral cavity, hence detailed investigations regarding the presence of $H$. pylori in the oral cavity have been of interest for some time. Current research shows that the bacterium resides in supragingival and subgingival plaques, in gingival and periodontal pockets, in dental pulp, on the dorsal surface of the tongue, in the mucous membranes, and in oncological lesions located in the oral cavity. Its relationship with the occurrence of pathological conditions such as caries, oral mucosa changes, periodontal diseases, plaque deposition, and other oral mucosal lesions is of continuous interest $[6,7]$.

The oral-oral route is considered to be the most common route of transmission of $H$. pylori infection, usually occurring in early childhood within the family. This is due to the close contact between parents and children and between siblings. Studies show that the main reason is a lack of adequate oral hygiene, the use of shared dishes and cutlery, and sharing a bed or bedroom with an infected person $[8,9]$. Some studies have stated that the risk of infection increases significantly when the mother is infected. Urita et al. performed a study of children from multigenerational families, in which they showed that not only infection in the mother but also in the grandmother is a significant risk factor for infection in children, while a larger number of family members and the presence of infection in the father or grandfather did not affect the transmission of infection [10]. A study conducted by Maciorkowska et al. showed that the H. pylori bacterial genome was evaluated in the same family in saliva in children and adults infected with $H$. pylori. These patients underwent gastroscopy examinations, and the presence of bacterial DNA was assessed by means of specific primers in collected specimens from the stomach. Genomic testing showed a high percentage of familial infections with the same strain, and in most children (68.2\%) the mother's vacuolating cytotoxin A (vacA) bacteria were found. Moreover, it was shown that siblings in the examined families were infected with a strain of the same vacA genotype in $58.8 \%$ of cases [11].

Another way by which $H$. pylori may be found in the saliva is through the oral-gastrointestinal route. Infection may occur through contaminated items such as toys shared by large groups of children. Contaminated endoscopic equipment may also be a source of infection for patients and medical personnel [12]. The gastro-oral route of $H$. pylori infection is also considered in the context of retrograde movement of stomach contents to the mouth during episodes of reflux or vomiting. Parzęcka et al. evaluated the prevalence of bacteria in the oral cavity in patients with gastroesophageal reflux disease. The authors concluded that the oral cavity is not always a reservoir of bacteria in the case of gastroesophageal reflux disease and concomitant $H$. pylori infection [13].

Infection can also occur through close contact with domestic animals. There is literature indicating the presence of Helicobacter in the saliva of dogs or cats. Jankowski et al. conducted a study among 30 dogs diagnosed with gastritis. The presence of the $H$. pylori genome in saliva was demonstrated in $76.6 \%$ of the studied animals. A number of species of bacteria were found with Helicobacter heilmannii being the most common, but $H$. salomonis, $H$. bizzozeronii, and $H$. pylori were also detected. The study suggests that Helicobacter is relatively common in dogs with gastritis, and their saliva may be a source of infection for humans and other animals [14]. Abdel-Raouf et al. came to similar conclusions, finding H. pylori in saliva in $45.3 \%$ of domestic dogs and $44.4 \%$ of domestic cats. The authors also found the presence of bacteria in salivary samples of $35.3 \%$ of stray dogs and $38.9 \%$ of stray cats [15].

\section{SALIVA AS A MATERIAL FOR TESTING FOR HELICOBACTER PYLORI - METHODS, UTILITY, PITFALLS}

Currently, the gold standard in the diagnosis of $H$. pylori infection in children and adolescents is an invasive method - gastroscopy with mucosal biopsies with a subsequent urease test and histopathological exam or bacterial culture of the biopsied tissue. Recently, some biomolecular studies have presented saliva as a biological material to indicate $H$. pylori infection. Currently this methods is used only in clinical tests [16]. The described method can probably be used in the future because saliva is easy to collect and store and it can be used to diagnose many diseases, including infectious, autoimmune, endocrine, cardiological, and neoplastic conditions and may also be used in assessing drug concentrations or in toxicological tests [17]. There are several ways to collect saliva: drainage (the patient swallows the saliva and allows its free flow to the sialometer), spitting out/expectoration (the subject actively spits saliva into the sialometer every 15-30 seconds), suction (collection of saliva accumulating on the bottom of the mouth using a vacuum aspirator), and absorption (using cotton swabs or gauze located near large salivary glands) [18]. Moreover, in an analysis carried out by Román-Román et al., vacA genotypes found in saliva and biopsies in the same patients were consistent in $51.1 \%$ of cases. The authors suggested that $H$. pylori may find its way to the oral cavity by different routes, and saliva may be involved in transmission of infection as well as being a source of re-infection [19]. Interesting results are presented by Yamada et al., who performed an examination of saliva, urine, and gastric juices. 
In 39 patients with confirmed of $H$. pylori DNA in gastric juices, they detected the bacterial genome in $71.8 \%$ of saliva samples. Urine samples from 26 of these patients were also collected, and a positive DNA result was obtained in $50 \%$ of the samples. The amount of DNA material of bacteria in gastric juices correlated with the presenting genome of $H$. pylori in saliva but did not correlate with the presence of $H$. pylori DNA in the urine [20].

\section{PREVALENCE AND CLINICAL CONSEQUENCES OF HELICOBACTER PYLORI PRESENCE IN THE MOUTH}

The presence of bacteria in the saliva raises questions and poses new challenges for scholars. The question remains whether there is a connection between gastritis and the presence of $H$. pylori in the oral cavity and saliva. The presence of $H$. pylori in the saliva is considered as a factor inducing periodontal disease: tooth decay and changes such as aphthous ulcers, leucoplakia, lichen planus, and even inflammatory processes in the palatine tonsils [21-23]. Therefore, attention should be payed to the hygiene of the oral cavity, which is the first section of the gastrointestinal tract, and early symptoms of many systemic diseases are often first noticed here $[24,25]$. Since $H$. pylori's isolation from the mouth, it is believed that this location may be a reservoir for further infection. Adler et al. showed that $H$. pylori found in saliva, and supra and subgingival plaques, may be considered as a reservoir of bacteria and one of the possible sources of infection and reinfection [26]. On the other hand, some authors suggest that the mouth is a natural living environment of H. pylori, which is located in small quantities, and only an imbalance in the bacterial flora can cause reinfection. With a proper microenvironment and normal immune response, this bacterium should not be a source of $H$. $p y$ lori infection in the stomach mucosa. Czesniekiewicz et al. also question the influence of this bacterium on the formation of periodontal diseases, recurrent aphthous stomatitis, inflammation of the tongue, and other inflammatory changes in the oral mucosa [27]. Quing-Hua Zou and Ren-Qing Li presented that re-infection of the gastric mucosa is quite frequent [28]. Interestingly, Lukes et al. analysed the genome of $H$. pylori detected in the throat and the stomach in the same individuals. The study confirmed the presence of bacteria in the throat [29]. On the other hand, Portuguese researchers, Veiga et al., negated the influence of $H$. pylori in the stomach and oral cavity on the frequency of caries. Studies in teenagers showed that in only $35.9 \%$ of the whole studied group, was H. pylori found in the gastric mucosa and only $1.9 \%$ of the bacteria was in the oral cavity. No correlation was found between the presence of this organism and dental caries. They confirmed the relationship between infection and sociodemographic factors such as age, place of residence, and socio-economic status [30].

\section{CONCLUSIONS}

There are still many questions about the mechanisms of $H$. pylori transmission, correlation with gastric mucosal infection, and the removal of dental plaques on the bacteria residing in saliva. It is not known whether its presence affects the pathological processes in the oral cavity or conversely the existing inflammation facilitates bacterial colonisation.

The presented data from the literature indicate a lack of conclusive findings, which in turn greatly motivate further research into the universality of $H$. pylori and its incompletely understood pathogenicity in clinical and social aspects.

In addition, a large number of available studies have focused on the infection of $H$. pylori in adults, although the infection often occurs in early childhood.

According to the latest recommendations, the examination of the presence of $H$. pylori in saliva remains only in scientific investigations. However, further studies are needed to evaluate the diagnostic profit from detecting the bacteria in saliva probes.

\section{DISCLOSURE}

The authors declare no conflict of interest.

\section{REFERENCES}

1. Urban J. Helicobacter pylori - Characteristics and pathogenic factors. Dent Med Probl 2010; 47: 482-486.

2. Łaszewicz W. The results of Helicobacter pylori infection researches. Trans Humana, Białystok 2004.

3. Krusiec-Świdergoł B, Kwiecień J, Jonderko K, et al. Zmniejszająca się częstość zakażeń Helicobacter pylori u dzieci w Polsce. Prz Gastroenterol 2010; 5: 279-284.

4. Piwowarczyk A, Horvath A, Szajewska H. Meta-analysis: the effects of Saccharomyces boulardii supplementation on Helicobacter pylori eradication rates and side effects during treatment. Aliment Pharmacol Ther 2010; 32: 1069-1079.

5. Hoffmann A, Krumbiegel P, Richter T, et al. Helicobacter pylori prevalence in children influenced by non-specific antibiotic treatments. Cent Eur J Public Health 2014; 22: 48-53.

6. Ogaya Y, Nomura R, Watanabe Y, et al. Detection of Helicobacter pylori DNA in inflamed dental pulp specimens from Japanese children and adolescents. J Med Microbiol 2015; 6: 117-123.

7. Kazanowska-Dygdała M, Radwan-Oczko M. Prevalence of Helicobacter pylori in the oral cavity - a literature review. Dental Forum 2013; 41: 79-82.

8. Rothenbacher D, Bode G, Berg G, et al. Helicobacter pylori among preschool children and their parents: evidence of parent-child transmission. J Infect Dis 1999; 179: 398-402.

9. Farrell S, Doherty GM, Milliken I, et al. Risk factors for Helicobacter pylori infection in children: an examination of the role played by intrafamilial bed sharing. Pediatr Infect Dis J 2005; 24: 149-152.

10. Urita Y, Watanabe T, Kawagoe N, et al. Role of infected grandmothers in transmission of Helicobacter pylori to children in a Japanese rural town. J Paediatr Child Health 2013: 49: 394-398.

11. Roszko I. Family Helicobacter pylori infection in the population of north-eastern region in Poland - morphology and molecular- 
genetics researches. A PhD Thesis. Medical Academy in Białystok 2006.

12. Duś I, Dobosz T, Manzin A, et al. Role of PCR in Helicobacter pylori diagnostics and research - new approaches for study of coccoid and spiral forms of the bacteria. Postepy Hig Med Dosw 2013; 9: 261-268.

13. Parzęcka M, Szaflarska-Popławska A, Gorzkiewicz M. Presence of Helicobacter pylori in the oral cavity of children and adolescents. Gastroenterol Pol 2012; 19: 95-98.

14. Jankowski M, Spużak J, Kubiak K, et al. Detection of Helicobacter spp. in the saliva of dogs with gastritis. Pol J Vet Sci 2016; 19: 133-140.

15. Abdel-Raouf M, Abdel-Gleel Y, Enab A. Study on the Role of Pet Animals for Helicobacter pylori Transmission. J Am Sci 2014; 10: 20-28.

16. Jones NL, Koletzko S, Goodman K, et al. Joint ESPGHAN/NASPGHAN Guidelines for the Management of Helicobacter pylori in Children and Adolescents (Update 2016). J Pediatr Gastroenterol Nutr 2017; 64: 1.

17. Kowalczyk P, Manda A, Kościelniak B, et al. Noninvasively collected, atypical biological materials in medical laboratory diagnostics. J Lab Diagn 2014; 50: 255-262.

18. Marcinkiewicz M, Markowski AR, Kreczko S. Methods of saliva sampling. Diagn Lab 1998; 34: 115-123.

19. Román-Román A, Giono-Cerezo S, Camorlinga-Ponce M, et al. VacA genotypes of Helicobacter pylori in the oral cavity and stomach of patients with chronic gastritis and gastric ulcer. Enferm Infecc Microbiol Clin 2013; 31: 130-135.

20. Yamada R, Yamaguchi A, Shibasaki K. Detection and Analysis of Helicobacter pylori DNA in the Gastric Juice, Saliva, and Urine by Nested PCR. Oral Sci Int 2008; 5: 24-34.

21. Kazanowska-Dygdała M, Duś I, Radwan-Oczko M. The presence of Helicobacter pylori in oral cavities of patients with leukoplakia and oral lichen planus. J Appl Oral Sci 2016; 24: 18-23.

22. Ding YJ, Yan TL, Hu XL, et al. Association of Salivary Helicobacter pylori Infection with Oral Diseases: a Cross-sectional Study in a Chinese Population. Int J Med Sci 2015; 12: 742-747.

23. Hwang MS, Forman SN, Kanter JA, Friedman M. Tonsillar Helicobacter pylori colonization in chronic tonsillitis: systematic review and meta-analysis. JAMA Otolaryngol Head Neck Surg 2015; 141 : 245-249.

24. Singhal S, Dian D, Keshavarzian A, et al. The role of oral hygiene in inflamatoy bowel diease. Dig Dis Sci 2011; 56: 170-175.

25. Dane A, Gubruz T. Clinical comperative study of effects of Helicobacter pylori colonization on oral health in children. Pak J Med Sci 2016; 32: 1-5.

26. Adler I, Muiño A, Aguas S, et al. Helicobacter pylori and oral pathology: Relationship with the gastric infection. World J Gastroenterol 2014; 20: 9922-9935.

27. Czesnikiewicz-Guzik M, Bielański W, Guzik TJ. Helicobacter Pylori in the oral cavity and its implications in gastric infection, periodontal health, immunology and dyspepsia; J Physiol Pharmacol 2005; 6: 77-89.

28. Zou QH, Li RQ. Helicobacter pylori in the oral cavity and gastric mucosa: a meta-analysis. J Oral Pathol Med 2011; 40: 317-324.

29. Lukeš P, Pavlík E, Potužníková B, et al. Comparison of Helicobacter pylori genotypes obtained from the oropharynx and stomach of the same individuals - a pilot study. Prague Med Rep 2012; 113: 231-239.

30. Veiga N, Pereira C, Resende C. Oral and Gastric Helicobacter Pylori: Effects and Associations. PLoS One 2015; 10: e0126923. 